\title{
PENGARUH PENGEMBANGAN KARIER DAN KOMPETENSI TERHADAP PRODUKTIVITAS KERJA SERTA IMPLIKASINYA PADA KINERJA PEGAWAI DINAS PU BINA MARGA WILAYAH KERJA SUMATERA SELATAN
}

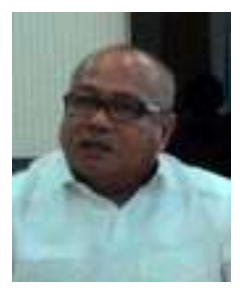

Oleh:

Dr. Ir. H. Samsul Bahri. M.M

Kepala Dinas PU Bina Marga Provinsi Sumatera Selatan

\begin{abstract}
ABSTRAK
Penelitian ini ditujukan adalah untuk mendeskripsi pengaruh kompetensi, pengembangan karier dan kompetensi kerja secara parsial maupun simultan terhadap produktivitas kerja dan implikasinya terhadap kinerja pegawai Dinas PU Bina Marga Wilayah Sumatera Selatan.

Metode penelitian yang digunakan dalam penelitian ini adalah metode survey deskriptif dan survey eksplanatori dengan ukuran sampel sebesar 207 responden, diambil dari populasi yang berjumlah 274. Metode analisis data yang digunakan dalam penelitian adalah SEM (Structural Equation Modeling). Pengujian model menggunakan Goodness of Fit sesuai dengan criteria yang diinginkan.

Berdasarkan hasil penelitian, maka didapatkan temuan sebagai berikut: pengembangan karier berpengaruh dan signifikan terhadap produktivitas. Kompetensi kerja berpengaruh dan signifikan terhadap produktivitas. Pengembangan karier dan kompetensi kerja secara bersama-sama berpengaruh positif dan signifikan terhadap produktivitas. Secara parsial, ternyata pengembangan karier lebih dominan memengaruhi produktivitas. Pengembangan karier berpengaruh positif dan signifikan terhadap kinerja pegawai. Kompetensi kerja berpengaruh positif dan signifikan terhadap kinerja pegawai. produktivitas berpengaruh positif dan signifikan terhadap kinerja pegawai. Dan Pengembangan karier, kompetensi kerja, dan produktivitas secara bersama-sama berpengaruh dan signifikan terhadap kinerja pegawai. Secara parsial, ternyata produktivitas lebih dominan memengaruhi kinerja pegawai.

Rekomendasi perlu dilakukan penelitian lanjutan untuk mengetahui variasi variabel lain yang memengaruhi kinerja pegawai, seperti variabel iklim organisasi, etos kerja. Kepemimpinan, budaya kerja dan motivasi kerja
\end{abstract}

Kata Kunci : Pengembangan karier, Kompetensi Kerja, produktivitas, Kinerja pegawai

\section{PENDAHULUAN}

Karier pegawai dan kompetensi pegawai mempunyai hubungan yang erat dengan produktivitas. Tingkat produktivitas kerja akan memengaruhi kinerja pegawai baik secara langsung maupun secara tidak langsung. Karena dalam pembinaan kepegawaian diperlukan penempatan pegawai sesuai kompetensi, adanya jaminan karier dan ukuran produktivitas kerja yang terukur.

Penempatan pegawai secara berkesinambungan sesuai dengan kebutuhan ditujukan untuk mendapatkan sumberdaya aparatur siap pakai, diawali dari analisis jabatan yang menggambarkan tentang kebutuhan sumber daya aparatur untuk suatu jabatan baru, reorganisasi struktur, maupun mutasi pegawai sebagai konsekwensi 
pegawai purna tugas atau mutasi jabatan dalam kontek penyegaran maupun rotasi secara berkala pada organisasi dan tidak mengesampingkan karier dari seorang pegawai yang sudah lama mereka bangun dalam organisasinya di mana mereka bekerja.

Dalam rangka pengembangan dan peningkatan kompetensi pegawai dibutuhkan pendidikan dan pelatihan yang terstruktur agar pegawai menjadi profesional dalam bidang tugasnya. Pendidikan dan pelatihan harus berorientasi pada hasil untuk memenuhi standar pelayanan minimal yang telah ditentukan oleh pemerintah.

Dalam upaya untuk merealisasikan hal itu terdapat banyak metode pembinaan pengembangan karier dan peningkatan kompetensi sumber daya aparatur, sebagaimana diungkapkan oleh

Abdurrahman (2006;148) sebagai berikut:

1. Meningkatkan kepribadian dan semangat pengabdian kepada organisasi dan masyarakat.

2. Meningkatkan mutu, kemampuan serta keterampilan baik dalam melaksanakan tugasnya maupun kepemimpinannya.

Dari pendapat Abdurahman dapat diperjelas bahwa bagi sumber daya aparatur itu harus memposisikan diri sebagai abdi atau pelayan masyarakat dalam artian mampu memberikan pelayanan prima pada sektor-sektor jasa yang diperlukan oleh masyarakat. Untuk memberikan pelayanan tersebut tidak terlepas dari kemampuan dam kompetensi dari masing-masing individu pegawai yang ditugaskan pada satuan kerja tempat bertugas.

Peraturan Pemerintah nomor 14 tahun 1994 tentang Pendidikan dan Pelatihan Pegawai Negeri Sipil. Membedakan jenis diklat bagi pegawai negeri sipil yang merupakan persyaratan untuk diangkat dari calon pegawai negeri sipil menjadi pegawai negeri sipil yang terlebih dahulu harus mengikuti pendidikan dan pelatihan, yaitu Pendidikan dan Pelatihan Prajabatan.

Kemudian menurut Abdurrahman (2006:246) tentang kondisi seharusnya pada pegawai dinyatakan bahwa, "pegawai akan menjadi pelaksana yang menunjang tercapainya tujuan, mempunyai tujuan, mempunyai pikiran, perasaan dan keinginan yang dapat mempengaruhi pikiran sikapsikapnya terhadap pekerjaannya. Sikap ini akan menentukan prestasi kerja, dedikasi dan kecintaan terhadap pekerjaan yang dibebankan kepadanya. Sikap-sikap positif harus dibina, sedangkan sikap-sikap negatif hendaknya dihilangkan sedini mungkin".

Dalam pengertian yang diungkapkan dapat di artikan juga bahwa produktivitas yang dinikmati dalam pekerjaan dengan memperoleh hasil tujuan kerja, penempatan, perlakuan, dan suasana lingkungan kerja yang baik bagi karyawan/pegawai. Dengan pemahaman seperti itu yang terjadi pada Dinas PU Bina Marga Wilayah Sumatera Selatan belum terlihat secara nyata dari aktivitas kesehariaannya.

Tolok ukur tingkat produktivitas pegawai mutlak tidak ada, karena setiap individu pegawai berbeda standarnya. Indikator produktivitas ini hanya diukur dengan kedisiplinan, moral kerja, dan penyelesaian tugas-tugas yang diberikan oleh atasan. Maka produktivitas pegawai di lingkungan Dinas PU Bina Marga Wilayah Sumatera Selatan masih rendah, hal ini dapat dilihat dari beberapa indikator seperti realisasi Anggaran Pendapatan dan Belanja Daerah (APBD) setiap tahun selalu tidak tercapai atau tidak sesuai dengan ketentuan yang semestinya pada tanggal 1 Januari anggaran tersebut telah menjadi APBD, sehingga pelaksanaan anggaran menjadi terlambat yang akan mengakibatkan proses 
pelaksanaan perencanaan tidak dapat dijalankan pada waktunya.

Jika dikaitkan dengan kompetensi pegawai di lingkungan Dinas PU Bina Marga Wilayah Sumatera Selatan pada saat ini masih dirasakan masih jauh dari harapan, hal ini disebabkan banyak faktor yang mempengaruhi, sebagai contoh adalah model penempatan pegawai sendiri tidak memperhatikan keahlian/basis pendidikan dari masing-masing pegawai secara individu yang ada serta untuk menempatkan para pegawai struktural tidak memperhatikan jenjang karier yang mereka persiapkan, hal ini terkesan bahwa karier para pegawai ditentukan oleh nasib atau tingkat kedekatan dengan pimpinan puncak.

Berdasarkan permasalahan tersebut di atas, maka dapat disusun sejumlah rumusan masalah sebagai berikut :

1. Apakah pengembangan karier memengaruhi produktivitas Pegawai Dinas PU Bina Marga Wilayah Kerja Sumatera Selatan?

2. Apakah kompetensi kerja terhadap memengaruhi produktivitas Pegawai Dinas PU Bina Marga Wilayah Kerja Sumatera Selatan?

3. Apakah pengembangan karier dan kompetensi kerja secara bersama-sama memengaruhi produktivitas?

4. Apakah pengembangan karier memengaruhi terhadap kinerja Pegawai Dinas PU Bina Marga Wilayah Kerja Sumatera Selatan?

5. Apakah kompetensi kerja memengaruhi kinerja Pegawai Dinas PU Bina Marga Wilayah Kerja Sumatera Selatan?

6. Apakah produktivitas memengaruhi kinerja Pegawai Dinas PU Bina Marga Wilayah Kerja Sumatera Selatan?

7. Apakah pengembangan karier, kompetensi kerja, dan produktivitas kerja secara bersama-sama memengaruhi kinerja Pegawai Dinas PU Bina Marga

Wilayah Kerja Sumatera Selatan?

\section{PENGEMBANGAN KARIER}

Pengembangan karier merupakan upaya atau langkah-langkah yang dilaksanakan oleh seorang pegawai dan atau oleh pimpinan sumber daya manusia dalam rangka pengembangan potensi pegawai untuk dapat menduduki jabatan yang lebih tinggi dalam usaha mencapai tujuan perusahaan. Keberhasilan pencapaian karier (Handoko, 2001:1) ditentukan oleh: 1) pendidikan formal, 2) pengalaman kerjanya, 3) sikap atasan, 4) prestasi kerja, 5) bobot pekerjaan, 6) lowongan jabatan, dan 7) produktivitas kerja.

Pentingnya pengembangan karier erat hubungannya dengan produktivitas pegawai, loyalitas, tingkat perputaran pegawai, dan kreativitas pegawai. Semakin jelas pelaksanaan pengembangan karier dalam suatu perusahaan akan menyebabkan semakin meningkat produktivitas pegawai, loyalitas, kreativitas pegawai, dan menurunnya tingkat perputaran pegawai. Menurut Matthews (2006:7) pengembangan karier adalah suatu upaya yang dilaksanakan setiap pegawai/organisasi untuk memacu dirinya agar berbuat yang optimal dalam mengabdi dan meningkatkan kemampuan. Pengembangan karier dalam penelitian ini adalah merupakan upaya atau langkahlangkah yang dilaksanakan oleh seorang pegawai dan atau oleh pimpinan sumber daya manusia dalam rangka pengembangan potensi pegawai untuk dapat menduduki jabatan yang lebih tinggi dalam usaha mencapai tujuan organisasi.

Pengembangan karier dalam penelitian ini meliputi delapan indikator, yaitu: 1) Jalur jabatan yang jelas, dengan indikator yang terdiri dari tingkat kejelasan urutan jenjang jabatan; 2) Rotasi jabatan, dengan indikator 
terdiri dari tingkat rotasi/perpindahan posisi jabatan; 3) Sistem terbuka kemampuan pegawai, dengan indikator terdiri dari tingkat keterbukaan akan pengakuan keahlian pegawai dan tingkat keberhasilan pegawai; 4) Kualifikasi pegawai, dengan indikator terdiri dari tingkat kesadaran atas pentingnya kualifikasi; 5) Penghargaan individual, dengan indikator terdiri dari tingkat penghargaan atas hasil; 6) Kaderisasi organisasi, dengan indikator tingkat pengkaderan untuk setiap jenjang karier, tingkat regenerasi dalam sistem kerja; 7) Program pendidikan dan latihan pegawai, dengan indikator Tingkat kesesuaian pelatihan dalam peningkatan karier; 8) Program promosi yang adil dan tidak ada diskriminasi, dengan indikator tingkat kemudahan pegawai dalam mengikuti pendidikan, tingkat keterbukaan dalam promosi jabatan.

\section{KOMPETENSI KERJA}

Menurut Cushway, (2000:216), Competency define as people based characteristic and implication on job effectiveness. Kompetensi kerja dapat dibagi atas dua kategori yaitu "threshold" dan "differentiating" menurut kinerja pegawai yang digunakan memprediksikan kinerja pegawai suatu pekerjaan. Menurut Mathis \& Jackson (2001; 241), competency is a base characteristic that correlation of individual or team performance achievement. Pengelompokan kompetensi kerja terdiri dari pengetahuan (knowledge), keterampilan (skill), dan kemampuan (abilities).

Berdasarkan teori di atas, maka kompetensi kerja dalam penelitian ini adalah merupakan kemampuan yang dimiliki pegawai dan bersifat spesifik yang menunjang dirinya dalam menyelesaikan pekerjaan. Dalam penelitian ini kompetensi kerja meliputi enam indikator, yaitu: 1)
Pengetahuan dalam organisasi/bekerja dan penyempurnaan cara kerja; 2) Orientasi standar kinerja pegawai, dengan indikator tingkat kesesuaian dengan standar hasil kerja; 3) Orientasi standar kinerja pegawai, dengan indikator tingkat kesesuaian kualitas kerja; Keahlian dan profesionalisme, dengan indikator tingkat kesesuaian keahlian dan profesionalisme pegawai dengan daya saing antar pegawai; 4) Kemampuan pengembangan keahlian, dengan indikator, dengan indikator tingkat dukungan organiasasi dalam pengembangan keahlian secara mandiri, tingkat dukungan organisasi dalam pengembangan keahlian pegawai; 5) Tanggung jawab dan efektivitas, dengan indikator tingkat kemudahan pegawai dalam mengikuti pendidikan, tingkat keterbukaan dalam promosi jabatan.

\section{PRODUKTIVITAS KERJA}

Yuki Dalam Usman (2008;108), menyatakan, produktivitas adalah sikap seseorang terhadap pekerjaannya yang mencerminkan pengalaman yang menyenangkan dan tidak menyenangkan dalam pekerjaannya serta harapanharapannya terhadap pengalaman masa depan. Berdasarkan beberapa kajian teori di atas, maka produktivitas pada penelitian ini adalah merupakan suatu sikap seseorang terhadap pekerjaannya yang mencerminkan pengalaman yang menyenangkan dan tidak menyenangkan dalam pekerjaannya serta harapan-harapannya terhadap pengalaman masa depan, yang diwujudkan dengan sikap emosional dan hasil kerja yang efisien, efektif dan produktif.

Robbins (2003:141) mendefinisikan produktivitas sebagai suatu sikap umum terhadap pekerjaan seseorang, selisih antara banyaknya ganjaran yang diterima seorang pekerja dan banyaknya yang mereka yakini seharusnya mereka terima. Tohardi 
(2002;28) menyatakan bahwa produktivitas merupakan sikap umum yang merupakan hasil dari beberapa sikap khusus terhadap faktor-faktor pekerjaan, penyesuaian diri dan hubungan sosial individu di luar kerja. Kemudian Menurut Handoko (2001;78) produktivitas adalah keadaan emosional yang menyenangkan atau tidak menyenangkan dengan mana para pegawai memandang pekerjaan mereka.

Dalam penelitian ini produktivitas meliputi delapan indikator, yaitu: 1) Kedudukan/posisi, dengan indikator tingkat pencapaian jabatan dalam organisasi dan tingkat kesesuaian jabatan yang diberikan; 2) Pangkat/golongan, dengan indikator Tingkat kesesuaian penghasilan didukung oleh pangkat dalam organisasi dan tingkat kesesuaian pekerjaan sesuai dengan imbalan yang diberikan; 3) Umur/masa kerja, dengan indikator kemampuan dalam bekerja dan tingkat kesesuaian dengan peningkatana kerja; 4) Jaminan finansial dan sosial, dengan indikator Tingkat kesesuaian pendapatan dengan kebuthan, tingkat kesesuaian jaminan yang dimiliki, tingkat kesesuaian jaminan sosial yang baik, dan tingkat kesesuaian pensiun mandiri; 5) karier organisasi, dengan indikator Tingkat kesesuaian kepentingan karier, tingkat kesesuaian dukungan rekan kerja, dan tingkat kesesuaian financial; 6) Pekerjaan yang menantang, dengan indikator Tingkat kesesuaian pekerjaan yang menantang dan tingkat kesesuaian proses pencapaian karier; 7) Promosi/tanggungjawab/status sosial, dengan indikator Tingkat kesesuaian dukungan organisasi atas promosi dan tanggungjawab jabatan dan tingkat kesiapan atas tugas jabatan; 8) Rekan kerja yang sesuai, dengan indikator Tingkat kesesuaian keberhasilan dengan rekan kerja, tingkat kesesuaian dukungan rekan kerja dalam bekerja, dan tingkat kesesuaian dengan rekan sejawat

\section{KINERJA PEGAWAI}

Mangkunegara

(2007:67)

mendefinisikan kinerja sebagai berikut: "Kinerja adalah hasil kerja secara kualitas dan kuantitas yang dicapai seorang pegawai dalam melaksanakan tugasnya sesuai dengan tanggung jawab yang diberikan kepadanya". Sementara itu Cushway (2000:379), mengatakan bahwa "kinerja pegawai tergantung pada kemampuan, usaha kerja dan kesempatan kerja yang dinilai dari out put".

Di samping itu, kinerja (performance) diartikan sebagai hasil kerja seseorang pegawai, sebuah proses manajemen atau suatu organisasi secara keseluruhan, dimana hasil kerja tersebut harus dapat ditunjukan buktinya secara konkrit dan dapat diukur. Berdasarkan beberapa kajian teori di atas, pada penelitian ini kinerja pegawai adalah merupakan suatu hasil kerja yang dicapai seseorang dalam melaksanakan tugas-tugas yang dibebankan kepadanya didasarkan atas kecakapan, pengalaman, kesungguhan serta waktu.

Dalam penelitian ini kinerja pegawai terdiri dari tujuh indikator, yaitu: 1) Ketepatan penyelesaian konsep rencana kerja, dengan indikator tingkat kesesuaian tugas dengan keunikan model kerja; 2) Kemampuan menyelesaikan masalah, dengan indikator Tingkat ketepatan waktu dalam menyelesaikan masalah dan tingkat kesesuaian waktu kerja; 3) Pembuatan model kerja, dengan indikator tingkat kemampuan mengembangkan sistem kerja secara mandiri dan sesuai SOP, tingkat kemudahan evaluasi pekerjaan; 4) Latar belakang pendidikan dan pengalaman, dengan indikator Tingkat kesesuaian latar belakang pendidikan dan pengalaman dalam 
menjalankan tugas pekerjaan, tingkat kesesuaian tingkat pendidikan; 5) Inisiatif mengatasi pekerjaan, dengan indikator tingkat kesesuaian inisiatif dalam mengatasi pekerjaan, tingkat pencapaian penyederhanaan pekerjaan; 6) Loyalitas jabatan, dengan indikator Tingkat loyalitas dan membantu rekan kerja; 7) Bekerjasama, dengan indikator tingkat kemampuan dalam memberikan kemudahan rekan kerja dalam melaksanakan pekerjaan, tingkat kesesuaian kerja dengan visi dan misi, tingkat kesesuaian kemampuan bekerja secara individu atau kelompok, tingkat kemampuan memimpin orang lain.

\section{KERANGKA PEMIKIRAN}

Berangkat tinjauan teori di atas, bahwa pengembangan karier dan kompetensi kerja memengaruhi produktivitas kerja baik secara parsial ataupun simultan. Pada gilirannya akan berimplikasi terhadap kinerja pegawai, yang memengaruhi secara parsial dan simultan. Kerangka pemikiran di atas tergambar dalam bagan alur pikir di bawah ini.

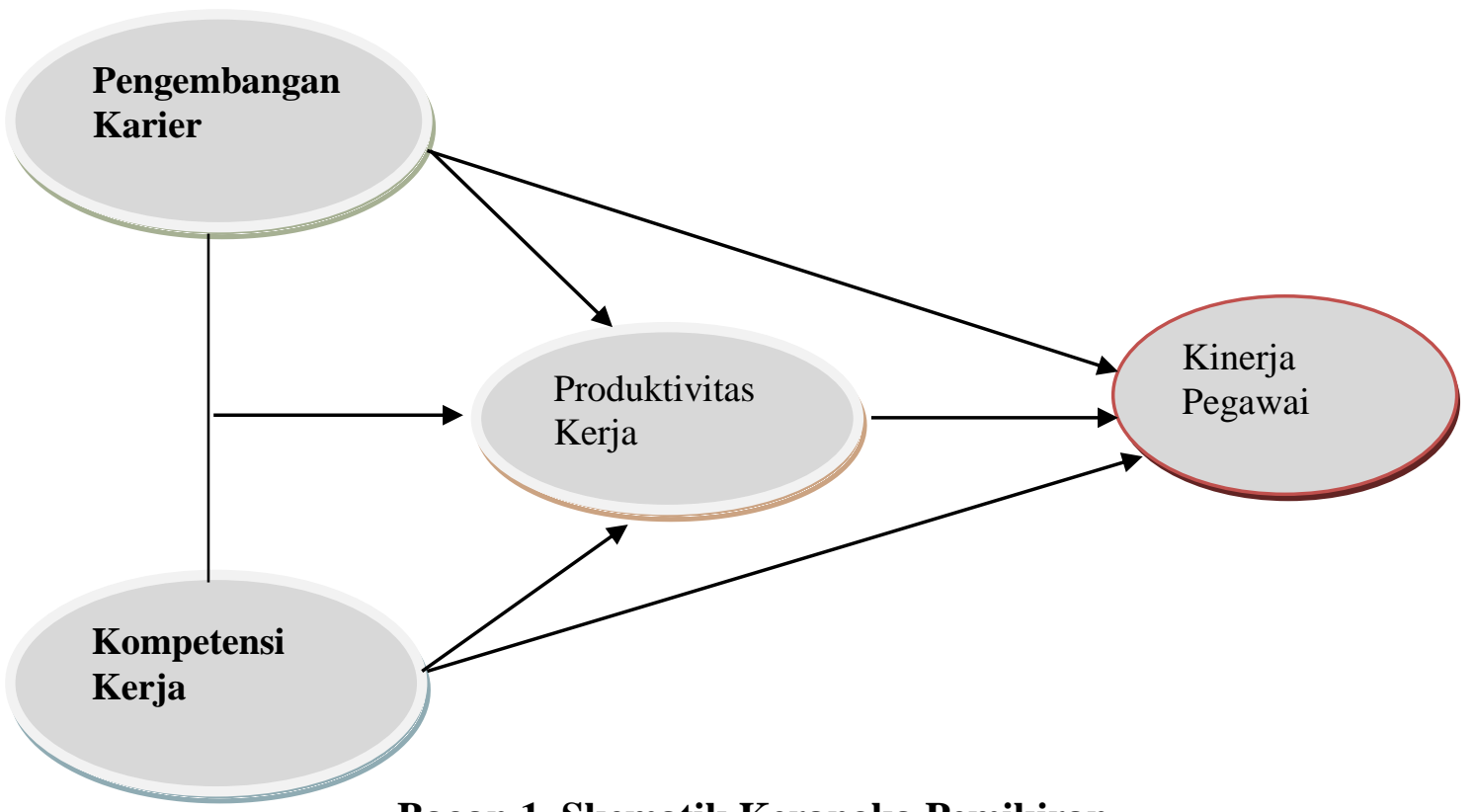

Bagan 1 Skematik Kerangka Pemikiran

\section{METODE PENELITIAN}

Tujuan studi dari penelitian ini adalah deskriptif dan verifikatif. Unit observasi adalah para pegawai struktural di lingkungan Dinas PU Bina Marga Wilayah Sumatera Selatan. Time horizon dalam penelitian ini adalah crossectional, yaitu informasi dari sebagian populasi (sampel responden) dikumpulkan langsung dari lokasi secara empirik.

Definisi operasional variabel dimaksudkan untuk memperjelas variabelvariabel yang akan diteliti, di mana pokok masalah dari penelitian ini adalah :
1. Pengembangan karier $\left(\xi_{1}\right)$ sebagai variabel bebas

2. Kompetensi kerja ( $\xi 2)$ sebagai variabel bebas

3. Produktivitas kerja $\left(\eta_{1}\right)$ sebagai variabel antara

4. Kinerja pegawai $\left(\eta_{2}\right)$ sebagai variabel terikat.

Populasi dalam penelitian ini adalah seluruh pegawai di lingkungan Dinas PU Bina Marga Wilayah Sumatera Selatan. Ukuran sampel ditentukan dengan memperhatikan teknik analisis yang digunakan dalam uji hipotesis yaitu model 
persamaan struktural (Structural Equation Model). Dalam penelitian ini terdapat 4 variabel sehingga diperlukan ukuran sampel minimum sebesar 200 responden, dengan mempertimbangkan terdapatnya data outliers (Hair et. al, 2006:605) dan pemilihan sampel digunakan teknik stratified random sampling.

\section{TEKNIK PENGUMPULAN DATA}

Penelitian ini merupakan penelitian persepsi dari responden penelitian adalah para Pegawai Dinas Pu Bina Marga Wilayah Kerja Sumatera Selatan, oleh karenanya jenis data dalam penelitian ini adalah data subjek (self-report data), dengan demikian data penelitian diperoleh langsung dari sumbernya yaitu (data primer) yaitu para Pegawai Dinas Pu Bina Marga Wilayah Kerja Sumatera Selatan.

Teknik pengumpulan data penelitian melalui penyebaran instrumen penelitian berupa kuesioner dengan menggunakan skala likert, dilengkapi dengan teknik observasi dan dokumentasi untuk mendapatkan data sekunder.

\section{RANCANGAN ANALISIS DATA}

Pengembangan karier diukur dengan delapan indikator, dan kompetensi kerja diukur dengan enam indikator . Selanjutnya, produktivitas diukur dengan delapan indikator, dan kinerja pegawai diukur dengan tujuh indikator. Analisis data menggunakan SEM-Listeral dengan langkah sebagai berikut; setelah diagram jalur lengkap berhasil dibuat, maka langkah selanjutnya adalah mengkonversi diagram jalur ke dalam bentuk persamaan, untuk pengukuran variabel laten eksogen, persamaan pengukuran untuk variabel laten endogen, dan persamaan struktural. Uji kesesuaian model dilakukan dengan menggunakan beberapa ukuran kesesuaian model (Goodness of Fit Test, GOF). Interpretasi model pada dasarnya melakukan diskusi atau pembahasan statistik terhadap hasil yang telah diperoleh.

Hasil pengolahan data untuk menguji kesesuai model yang sudah fit dan dapat diterima, maka hasil yang diperoleh diringkas dalam tabel berikut

Tabel Ukuran Kesesuaian Model

\begin{tabular}{|l|l|l|l||}
\hline \multicolumn{1}{|c|}{$\begin{array}{c}\text { Indikator } \\
\text { GOF }\end{array}$} & $\begin{array}{c}\text { Ukuran yang } \\
\text { Diharapkan }\end{array}$ & $\begin{array}{c}\text { Hasil } \\
\text { Estimasi }\end{array}$ & \multicolumn{1}{|c||}{ Kesimpulan } \\
\hline \hline \multicolumn{4}{|c|}{ Absolute Fit } \\
\hline GFI & GFI $>0,90$ & 0,96 & Goodness of Fit \\
\hline RMSEA & RMSEA $<0,08$ & 0,05 & Goodness of Fit \\
\hline \multicolumn{4}{|c|}{ Incremental Fit } \\
\hline NNFI & NNFI $>0,90$ & 0,93 & Goodness of Fit \\
\hline NFI & NFI $>0,90$ & 0,94 & Goodness of Fit \\
\hline AGFI & AGFI $>0,90$ & 0,90 & Goodness of Fit \\
\hline RFI & RFI $>0,90$ & 0,90 & Goodness of Fit \\
\hline IFI & IFI $>0,90$ & 0,97 & Goodness of Fit \\
\hline CFI & CFI $>0,90$ & 0,97 & Goodness of Fit \\
\hline
\end{tabular}

Sumber : Hasil Pengolahan dengan LISREL 8. 30 
Dari tabel di atas, delapan ukuran kesesuaian yang diperoleh memiliki indeks kesesuaian model goodness of fit. Selanjutnya dapat diteruskan pada analisis lebih lanjut, karena dekat dengan kriteria ukuran good fit (Hair, Andersen, Tatham, dan Black, 2006 :623).
Model penuh persamaan SEM diperoleh model diagram lintasan, yaitu model standardized seperti ditunjukkan pada Gambar berikut:

\section{Output Pengolahan Data Dengan SEM (Standardize Model)}

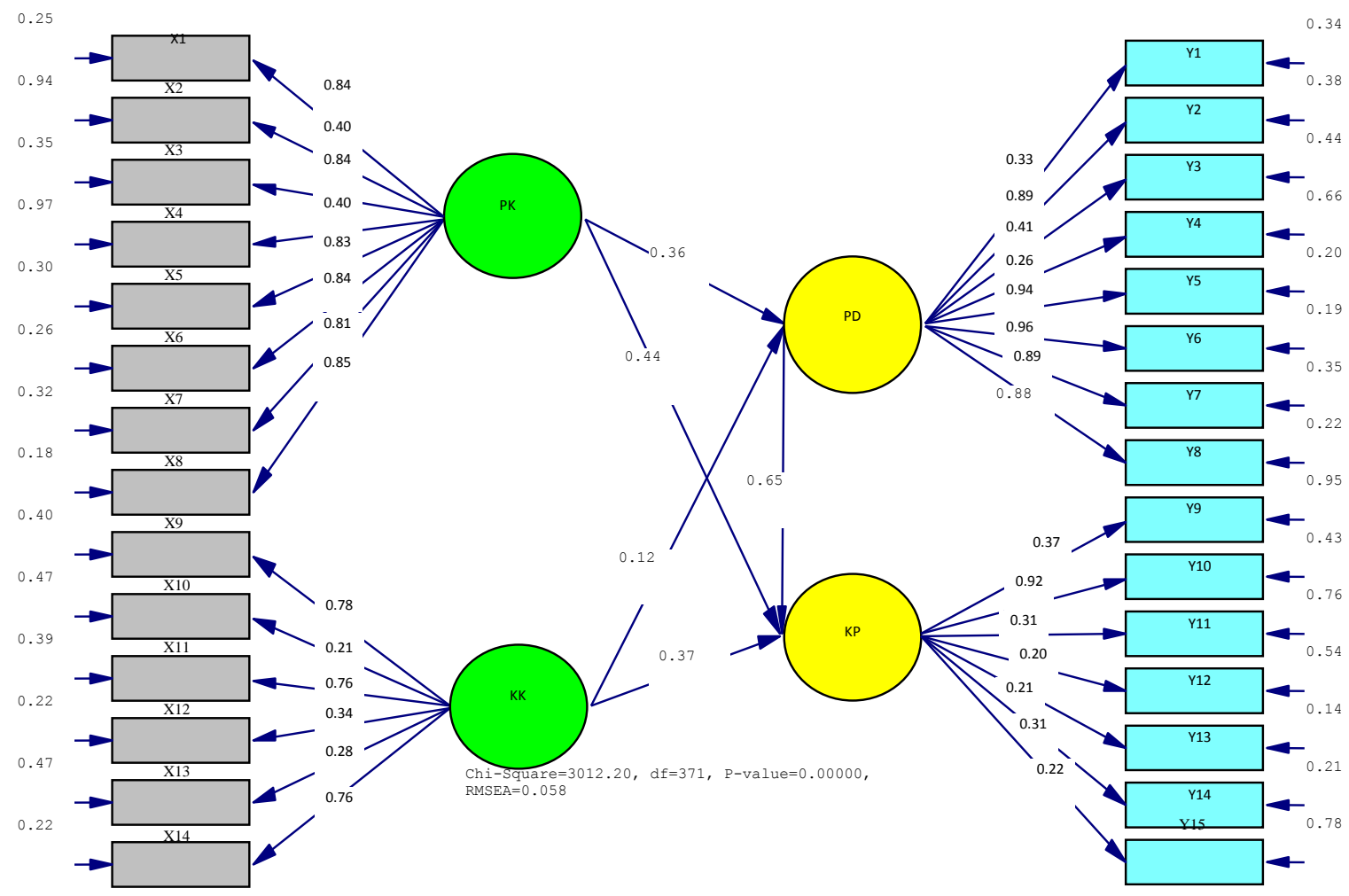

$\mathrm{PK}=$ Pengembangan karier

$\mathrm{KK}=$ Kompetensi Kerja

$\mathrm{PD}=$ produktivitas

$\mathrm{KP}=$ Kinerja pegawai

\section{HASIL PENGUJIAN HIPOTESIS}

Dari 7 hipotesis yang diajukan penelitian, telah memperoleh model persamaan struktural, semua hipotesis dapat diterima dengan rincian sebagai berikut;

Hipotesis 1 dapat diterima :

Dengan demikian maka pengembangan karier berpengaruh positif dan signifikan terhadap produktivitas kerja, besarnya pengaruh langsung variabel pengembangan karier terhadap produktivitas adalah sebesar 0,38.

Hipotesis 2 dapat diterima.

Dengan demikian kompetensi kerja berpengaruh positif dan signifikan terhadap produktivitas kerja, dengan besarnya pengaruh langsung kompetensi kerja terhadap produktivitas adalah sebesar 0.12. 
Hipotesis 3 dapat diterima.

Dengan demikian secara bersama-sama pengembangan karier dan kompetensi kerja berpengaruh positif dan signifikan terhadap produktivitas. maka Pengaruh secara bersamasama variabel pengembangan karier dan kompetensi kerja terhadap produktivitas adalah sebesar 12,25\%, sisanya sebesar $87.75 \%$ dipengaruhi oleh variasi variabel lain. Pengaruh pengembangan karier, kompetensi Kerja terhadap produktivitas pegawai. Hasil yang diperoleh untuk model persamaan struktural, sesuai dengan hipotesis yang diajukan secara parsial pengembangan karier berpengaruh signifikan terhadap produktivitas pegawai, artinya semakin baik pengembangan karier, maka produktivitas pegawai akan meningkat.

Hipotesis 4 dapat diterima.

Dengan demikian pengembangan karier berpengaruh positif san signifikan terhadap kinerja pegawai dengan besaran pengaruh langsung produktivitas terhadap kinerja adalah sebesar 0,44.

Hipotesis 5 dapat diterima.

Dengan demikian kompetensi kerja berpengaruh signifikan terhadap kinerja pegawai, dengan besaran pengaruh variabel kompetensi terhadap kinerja pegawai adalah sebesar 0,37 .

Hipotesis 6 diterima.

Dengan demikian produktivitas pegawai berpengaruh positif dan signifikan terhadap kinerja pegawai, dengan besaran pengaruh produktivitas kerja terhadap kinerja jabatan adalah sebesar 0,83 .

Hipotesis 7 dapat diterima.

Dengan demikian maka secara bersama-sama pengembangan karier, kompetensi kerja, dan produktivitas berpengaruh positif dan signifikan terhadap kinerja pegawai. Besaran pengaruh variabel pengembangan karier, variabel kompetensi kerja, variabel produktivitas secara simultan terhadap kinerja pegawai adalah sebesar 62, $41 \%$, sisanya sebesar $37,59 \%$ dipengaruhi oleh variasi variabel lain. Dengan demikian kinerja pegawai Dinas PU Bina Marga Wilayah Sumatera Selatan dipengaruhi secara positif dan signifikan oleh pengembangan karier, kompetensi kerja, dan produktivitas.

\section{KESIMPULAN PENELITIAN}

Berdasarkan Pembahasan dalam penelitian maka dapat ditarik kesimpulan sebagai berikut:

1. Pengembangan karier terbukti berpengaruh positif dan signifikan terhadap produktivitas pegawai Dinas PU Bina Marga Wilayah Sumatera Selatan dengan indikator yang paling dominan memengaruhi adalah indikator program promosi yang berkeadilan dan tanpa diskriminasi. Hal ini sejalan dengan teori Handoko (2001:71).

2. Kompetensi kerja pegawai terbukti berpengaruh positif dan signifikan terhadap produktivitas pegawai Dinas PU Bina Marga Wilayah Sumatera Selatan dengan indikator yang paling dominan memengaruhi adalah indikator pengetahuan, keterampilan dan kemampuan. Hal ini sejalan dengan teori Schuller dan Jackson dalam Wibowo (2006:69).

3. Pengembangan karier dan kompetensi kerja pegawai terbukti signifikan secara bersama-sama memiliki kontribusi terhadap produktivitas pegawai Dinas PU Bina Marga Wilayah Sumatera Selatan. Apabila dilihat secara parsial, ternyata pengembangan karier lebih dominan memengaruhi produktivitas 
dengan indikator yang paling dominan mempengaruhi adalah indikator program promosi yang berkeadilan dan tanpa diskriminasi. Hal ini sejalan dengan teori Robbins Stephen (2003).

4. Pengembangan karier terbukti berpengaruh positif dan signifikan terhadap kinerja pegawai Dinas PU Bina Marga Wilayah Sumatera Selatan dengan indikator yang paling dominan memengaruhi adalah indikator program promosi yang berkeadilan dan tanpa diskriminasi. Hal ini sejalan dengan teori Matthews (2006:7).

5. Kompetensi kerja pegawai terbukti berpengaruh positif dan signifikan terhadap kinerja pegawai Dinas PU Bina Marga Wilayah Sumatera Selatan dengan indikator yang paling dominan memengaruhi adalah indikator pengetahuan, keterampilan dan kemampuan. Hal ini sejalan dengan teori dari Cushway (2000:216).

6. Produktivitas kerja terbukti berpengaruh positif dan signifikan terhadap kinerja pegawai Dinas PU Bina Marga Wilayah Sumatera Selatan dengan indikator yang paling dominan mempengaruhi adalah indikator pekerjaan yang secara mental menantang. Hal ini sejalan dengan teori dari Robbins (2003:141).

7. Pengembangan karier, kompetensi kerja pegawai, dan produktivitas terbukti signifikan secara bersama-sama memiliki kontribusi terhadap kinerja pegawai Dinas PU Bina Marga Wilayah Sumatera Selatan. Tetapi dilihat secara parsial, ternyata produktivitas lebih dominan mempengaruhi kinerja pegawai dengan indikator yang paling dominan mempengaruhi adalah indikator pekerjaan yang secara mental menantang. Hal ini sejalan dengan teori dari Cushway (2000:95).

\section{IMPLIKASI MANAJERIAL}

Beranjak dari hasil penelitian di atas, diperoleh temuan bahwa kinerja pegawai terutama kemampuan pegawai dalam menyelesaikan masalah pada Dinas PU Bina Marga Wilayah Sumatera Selatan akan meningkat apabila pegawai memiliki produktivitas yang tinggi terutama pada unsur pekerjaan yang secara mental menantang, di mana produktivitas pegawai akan tinggi apabila pengembangan karier dengan baik terutama pada program promosi yang berkeadilan dan tanpa diskriminasi, serta didukung oleh pegawai memiliki kompetensi kerja yang tinggi terutama pada pengetahuan, keterampilan dan kemampuan.

\section{REKOMENDASI PENELITIAN}

1. Variasi variabel diluar variabel penelitian ini, seperti iklim organisasi, etos kerja, kompensasi, motivasi, kepemimpinan, dan faktor lainnya dapat memengaruhi kinerja pegawai di Lingkungan Pemerintah Daerah Dinas PU Bina Marga Wilayah Sumatera Selatan,.

2. Hasil penelitian ini dapat juga diterapkan pada Jabatan Struktural pada Pemerintahan Daerah lain di Indonesia. Karena itu diharapkan penelitian ini dilanjutkan dengan objek yang berbeda, sehingga manfaat hasil penelitian ini akan menjadi lebih luas.

3. Penelitian ini menggunakan teknik analisis SEM (Structural Equation Modeling) dengan variabel produktivitas pegawai sebagai variabel antara (intervening). Pada penelitian selanjutnya dapat dilakukan dengan variabel yang sama tetapi dengan menggunakan produktivitas pegawai sebagai variabel moderasi (moderating), maka kemungkinan hasil penelitian akan berbeda. 


\section{Kepustakaan}

Arikunto, Sukarsimi. 2002. Prosedur Penelitian Suatu Pendekatan Praktek. Jakarta : PT. Rineka Cipta.

Aswi, 2008. Melejitkan karier Dalam Waktu Setahun, Jakarta. Hi-Fest Publishing

Cushway, Barry, dkk., 2000. Perilaku \& Desain Organisasi, terjemahan Agus Dharma, Jakarta: Elex Media Komputindo

Fathoni, Abdurrahmat. 2006. Organisasi dan Manajemen Sumber Daya Manusia. Jakarta : PT Rineka Cipta.

Hair et al., (2006), Multivariate Data Analysis, Fifth Edition, Prentice Hall, Upper Saddle River : New Jersy.

Handoko, T. Hani. 2001. Manajemen Personalia dan Sumber Daya Manusia. Yogyakarta : BPFE Yogyakarta.

Holtzman \& Vezzu . 2011. Confirmatory Factor Analysis and Structural Equation Modeling of Noncognitive Assessments using PROC CALIS. Research Data Analyst, Center for Data Analysis Research, Educational Testing Service, Princeton
Mangkunegara, Anwar Prabu. 2007. Evaluasi Kinerja SDM. Bandung : PT.Refika Aditama

Mathis RL dan JH Jackson. 2001. Manajemen Sumber Daya Manusia. Buku I. Jakarta. PT Salemba Emban Patria.

Matthews, Virginia, 2006. Searching for Job Satisfaction : Liverpool Hope University. online, (2007 August 10), available from: URL : http://media.com/searchCRM/do wnloads/ CallCenterFDch17.pdf

Moekijat, 2007. Perencanaan dan Pengembangan karier Pegawai. Bandung, CV. Mandar Maju.

Robbins, Stephen P. 2003, Perilaku Organisasi, Jilid I, Jakarta : PT. Prenhallindo.

Sugiyono, 2006. Metode Penelitian Bisnis. Bandung : CV. Alfabetta.

Tohardi, Ahmad. 2002. Pemahaman Praktis Manajemen Sumber Daya Manusia. Bandung : CV. Mandar Maju.

Usman, Husaini . 2008 . Manajemen; Teori, Praktik, dan Riset Pendidikan, Edisi Kedua. Jakarta : PT. Bumi Aksara

Wibowo, 2006. Manajemen Perubahan. Jakarta : PT. Raja Grafindo Persada. 
